Article

\title{
Description of the Annual Reproductive Cycle of Wreckfish Polyprion americanus in Captivity
}

\author{
Maria Papadaki ${ }^{1}$, José Benito Peleteiro ${ }^{2}$, Blanca Alvarez-Blázquez ${ }^{2}{ }^{\circledR}$, \\ José Luis Rodríguez Villanueva ${ }^{3}$, Fatima Linares ${ }^{4}$, Antonio Vilar ${ }^{5}$, Evaristo Pérez Rial ${ }^{2}$, \\ Nuria Lluch ${ }^{2}$, Ioannis Fakriadis $\left.{ }^{1} \mathbb{(}\right)$, Irini Sigelaki ${ }^{1}$ and Constantinos C. Mylonas ${ }^{1, *}$ \\ 1 Institute of Marine Biology, Biotechnology and Aquaculture, Hellenic Center for Marine Research, \\ P.O. Box 2214, 71500 Heraklion, Crete, Greece; mpapadak@hcmr.gr (M.P.); fakriadis@hcmr.gr (I.F.); \\ sigelakr@hcmr.gr (I.S.) \\ 2 Instituto Español de Oceanografia, Centro Oceanográfico de Vigo, 36280 Vigo, Spain; \\ tito.peleteiro@gmail.com (J.B.P.); blanca.alvarez@ieo.es (B.A.-B.); evaristo.perez@ieo.es (E.P.R.); \\ nuria.lluch@ieo.es (N.L.) \\ 3 Instituto Galego de Formación en Acuicultura, Xunta de Galicia, 36626 Illa de Arousa, Spain; \\ xose.luis.rodriguez.villanueva@xunta.es \\ 4 Centro de Investigacións Mariñas, Xunta de Galicia, 36620 Vilanova de Arousa, Pontevedra, Spain; \\ fatima.linares.cuerpo@xunta.gal \\ 5 Aquarium Finisterrae, 15002 A Coruña, Spain; antonio@casaciencias.org \\ * Correspondence: mylonas@hcmr.gr; Tel.: +30-2810-337878
}

Received: 10 August 2018; Accepted: 17 October 2018; Published: 19 October 2018

\begin{abstract}
Successful spontaneous reproduction and the production of viable offspring of wild fish in captivity can take some years of adaptation, and may also involve different environmental conditions, sex ratios and densities compared to natural populations. We followed the reproductive cycle of wreckfish Polyprion americanus-a late maturing, deep-sea benthic species-in captivity in three different broodstocks in Spain under natural photoperiod and temperature, and one broodstock in Greece under a constant temperature of $16{ }^{\circ} \mathrm{C}$ for two consecutive years, to describe the reproductive cycle of the species and the associated sex steroid hormone profiles. Oogenesis begun in the fall and post-vitellogenic oocytes of $1250 \mu \mathrm{m}$ were present between March and June. Males were in spermiation condition and produced good-quality sperm throughout the year, regardless of the temperature profile to which they were exposed. Some females completed oogenesis, underwent oocyte maturation, and spawned spontaneously under both constant and fluctuating temperatures. The sex steroid hormones of both males and females followed the already-known profiles during fish gametogenesis, except for 17,20ß-dihydroxy-progesterone, which did not seem to be related to either female or male maturation. The female reproductive dysfunctions that were identified included (a) the arrest of oogenesis at the cortical alveoli stage in certain females; (b) the failure to undergo oocyte maturation in others; and (c) the production of large percentages of unfertilized eggs from the females that spawned spontaneously. Our study suggests that reproduction in captivity is possible in wreckfish maintained under typical marine aquaculture conditions, but that reliable spawning and production of high-quality eggs may require some years of adaptation to captivity, before the reproductive dysfunctions will be overcome.
\end{abstract}

Keywords: wreckfish; Polyprion; gametogenesis; broodstock management; spawning

\section{Introduction}

The wreckfish Polyprion americanus is a globally distributed fish inhabiting continental coasts and oceanic islands at depths of 100-1000 m [1,2]. The species forms three genetically distinct stocks: 
in the North Atlantic and the Mediterranean Sea, off the coast of Brazil and in the South Pacific [3]. A gonochoristic species with no sexual dimorphism, it spawns at the continental slope at depths of 300-500 m, with the formation of spawning aggregations [4]. Its rapid growth even at relatively low temperatures, its late maturation and good adaptation to captivity $[1,5]$, together with its limited landings from the capture fisheries, high flesh quality and market value make the wreckfish an excellent candidate for the diversification of aquaculture production. In the southern hemisphere in New Zealand, viable eggs and larvae have been obtained from wild broodstocks of the congener hāpuku Polyprion oxygeneios [6]. In addition, juvenile production by F1 generation breeders was achieved more recently [7] and experiments have been carried out on the advancement of puberty and the ovarian development of the species [8]. In the wreckfish, however, although attempts have been made to control its reproduction and produce viable eggs, spawning has been inconsistent, and the produced eggs often exhibit low fertilization [9]. There is therefore a need for a more detailed study of the reproductive function of this species in captivity, before its maturation and spawning can be reliably controlled for the purposes of aquaculture.

When reared in captivity, fish often exhibit reproductive dysfunctions, which can result in the lack of spawning and the production of fertilized eggs [10,11]. Examples of reproductive dysfunctions observed in female fish held in captivity include: the lack of gametogenesis of European eel Anguilla anguilla [12]; the lack of maturation and ovulation in the meagre Argyrosomus regius and the greater amberjack Seriola dumerili $[13,14]$ at the end of vitellogenesis [15]; and the failure of breeding and spawning of F1 generation sharpsnout seabream Diplodus puntazzo [16,17] and Senegalese sole Solea senegalensis [18]. In males, reproductive dysfunctions mainly involve reduced sperm production or lack of breeding and spawning [19], whereas, as in the females, European and Japanese eel Anguilla japonica males remain immature and fail to undergo spermatogenesis at all in captivity [20]. The monitoring and description of the reproductive cycle of new/potential species for aquaculture production may enable the recognition of any reproductive dysfunctions and lead to the development of protocols for controlling reproduction, spawning induction and production of viable/fertilized eggs [15]. In addition, description of the reproductive cycle in captivity allows for the identification of the reproductive and spawning periods, environmental preferences (temperature and photoperiod), spawning kinetics, gamete production characteristics such as batch fecundity and annual fecundity, fertilization success, sperm characteristics, etc. All these parameters are very important for the proper broodstock management of any aquaculture species.

The aim of the present study was to describe for the first time the reproductive cycle of wreckfish in captivity, by following oocyte growth and maturation stage, sperm quality variations and the associated sex steroid plasma concentrations in four different captive broodstocks of wreckfish maintained under different conditions in Spain and Greece, for almost two consecutive years. Rearing conditions included the following: natural fluctuating temperatures in Spain mimicking what is common in marine aquaculture hatcheries; constant annual temperature of $16{ }^{\circ} \mathrm{C}$ in Greece, mimicking what is present in the great depths where mature wreckfish are found (mostly between 500-850 m) [21] and where they probably undergo reproductive maturation. The study provides information concerning the broodstock management of the species and will contribute to the development of reproduction control methods for this potentially important aquaculture species.

\section{Results}

At the Hellenic Center for Marine Research (HCMR, Greece), where fish were maintained under constant temperature, vitellogenesis was already in progress in October, with the female having oocytes of $600 \mu \mathrm{m}$ in diameter (Figures 1a and 2a). In December, two months later, vitellogenesis continued and the oocytes reached a mean diameter of $900 \mu \mathrm{m}$. Up to this time, the ovarian biopsies also contained remnants from the matured oocytes from the previous reproductive season, appearing as shiny amber masses (Figure 1a,b). The asynchronous nature of oogenesis was apparent in the December biopsies, with a large size variation of vitellogenic oocytes, ranging in diameter from 600 
to $900 \mu \mathrm{m}$ (Figures $1 \mathrm{~b}$ and $2 \mathrm{~b}$ ). At the January sampling the biopsies were now almost completely occupied with advanced vitellogenic oocytes of $1100 \mu \mathrm{m}$ (Figures 1c and 2c) and in the following 3 months the oocytes reached the maximum vitellogenic size of $1250 \mu \mathrm{m}$, at the size that early oocyte maturation (OM) begins (Figure 1d). The early stages of OM were recognized by the coalescence of the lipid droplets, becoming progressively more intense within the oocyte and more prevalent within the ovary (Figures 1e and $2 \mathrm{~d}, \mathrm{e}$ ) and by the migration of the germinal vesicle to the oocyte periphery (Figure 2d,e). A significant increase in oocyte diameter took place during this process, whereby the oocytes reached $1500 \mu \mathrm{m}$ in size. Finally, all lipid droplets fused into a single mass located in the center of the oocyte (Figures $1 \mathrm{f}$ and 2f). The yolk globules then also began to coalesce into progressively larger masses, resulting in a further clearing of the cytoplasm and an increase in oocyte diameter (Figures $1 \mathrm{~g}$ and $2 \mathrm{~g}$ ). A similar progression of oocyte development was observed in the stocks of Spain, varying slightly in time (not shown).

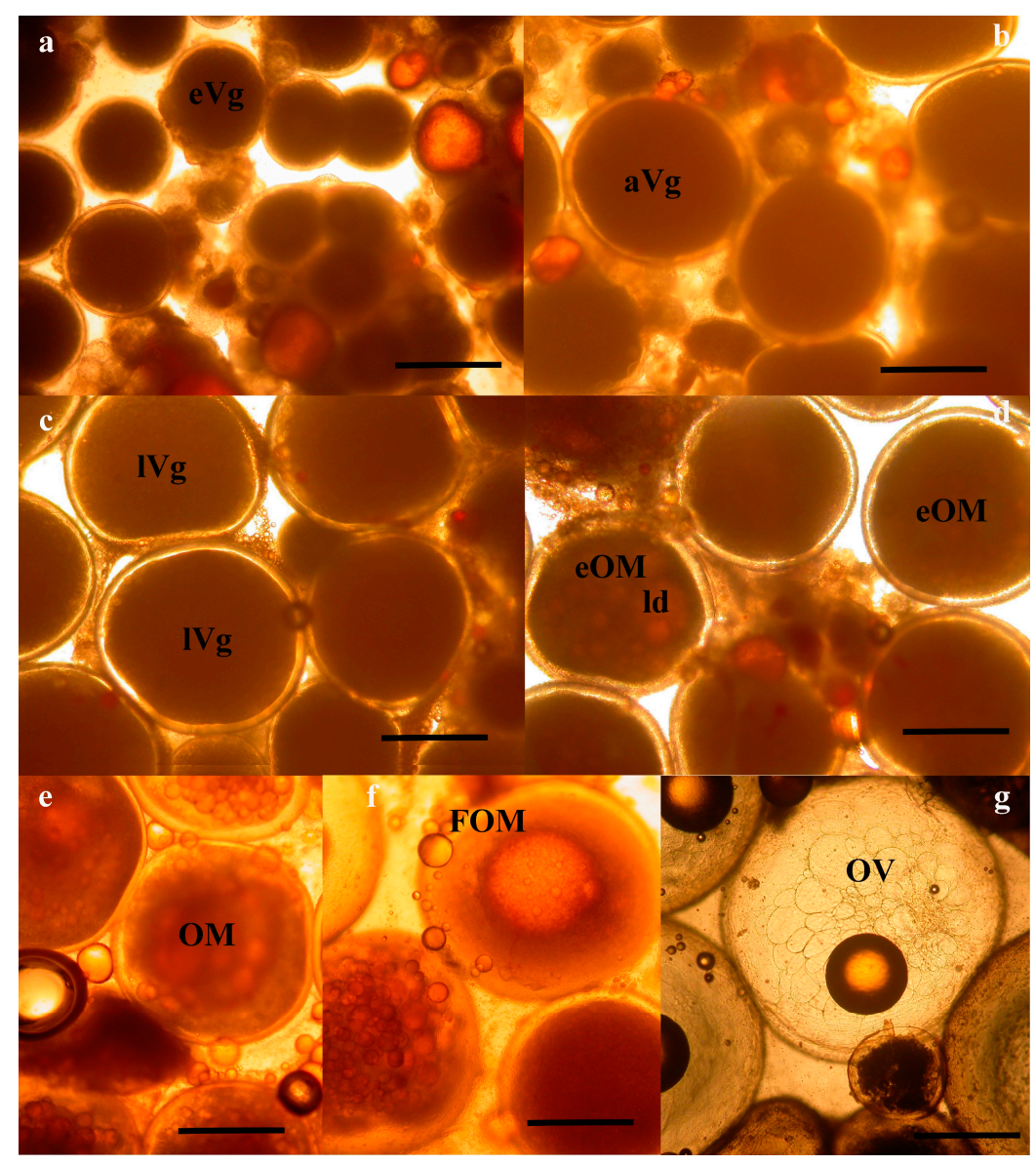

Figure 1. Photomicrographs of wet mount wreckfish biopsies, showing oocytes at successive stages of development: (a) early vitellogenesis (eVg); (b) advanced vitellogenesis $(\mathrm{aVg})$; (c) late vitellogenesis $(\mathrm{Vg})$; (d) early ovarian maturation (eOM) with lipid droplet (ld) coalescence; (e) advanced oocyte maturation (OM); (f) final oocyte maturation (FOM); and (g) ovulation (OV). The bar is $500 \mu \mathrm{m}$. 


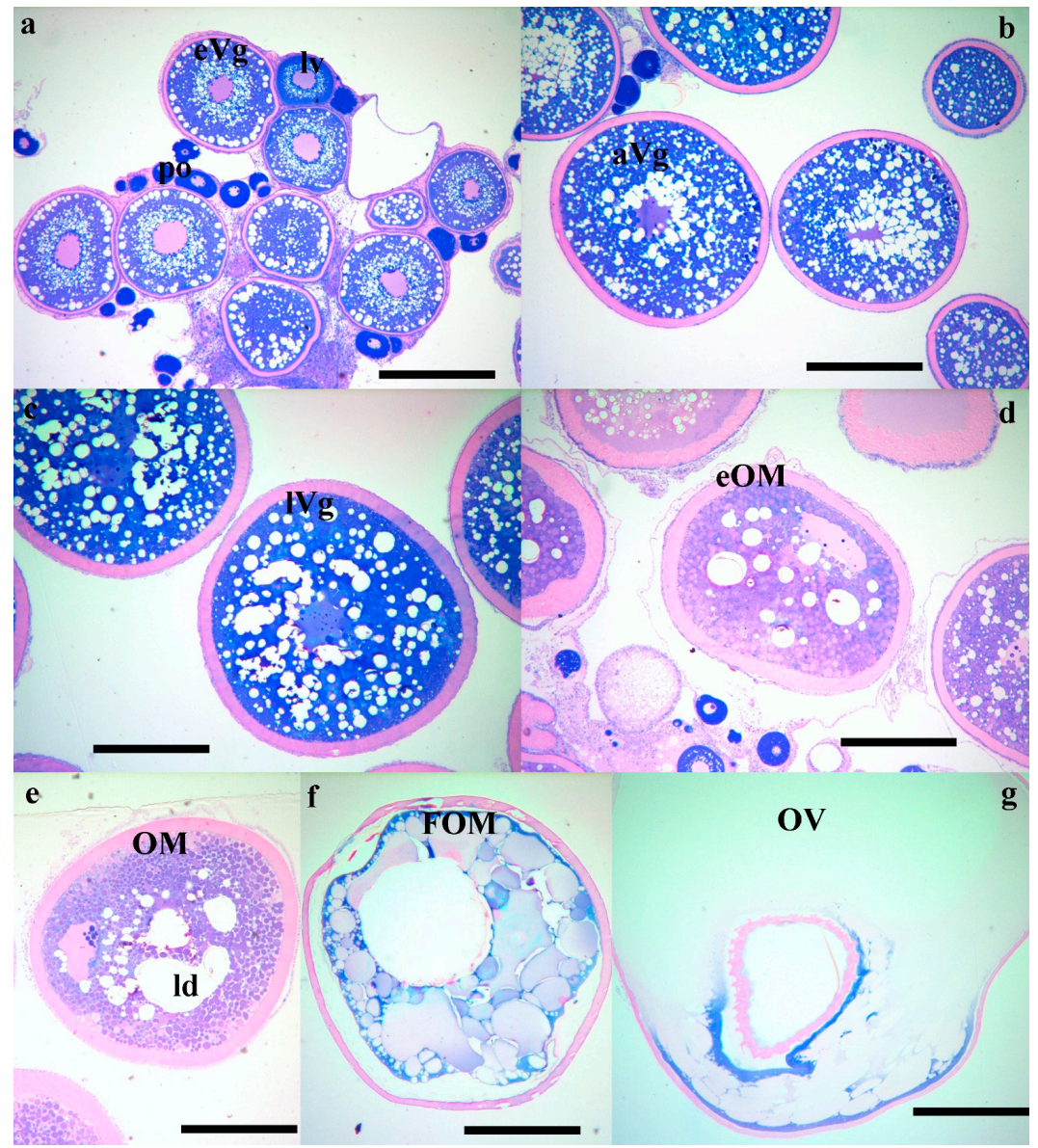

Figure 2. Photomicrographs of histological sections of wreckfish biopsies, showing: (a) primary (po), lipid vesicle (lv) and early vitellogenic oocytes (eVg); (b) advanced vitellogenic oocytes (aVg); (c) late vitellogenic oocytes (lVg); (d) early maturing oocytes with lipid droplet coalescence (eOM); (e) advanced maturation oocytes (OM) with further coalescence of the lipid droplets (ld); (f) oocytes at the FOM stage; and (g) ovulated oocytes (OV). Histological sections were stained with methylene blue/basic fuchsin, and the bar is $500 \mu \mathrm{m}$.

Oocyte diameter in the fish at HCMR reached its highest values in May in both years of the study (Figure 3a); however, in the wreckfish stocks kept in Spain some of the monitored females did not advance beyond the cortical alveoli stage, and their oocytes did not reach more than $350 \mu \mathrm{m}$ in diameter during the whole year (four females from Instituto Español de Oceanografía (IEO) and two females from Conselleria do Medio Rural e Mariño (CMRM)). These females were excluded from the calculations of mean oocyte diameter (Figure 3b). Variation of the oocyte diameter between individual females of the Spanish stocks in the same month was observed during the study; this variation explains the lower mean oocyte diameter value of the Spanish broodstocks compared to the HCMR broodstock (Figure 3a,b). The first significant increase of oocyte diameter was observed when oocytes entered vitellogenesis, with oocytes reaching around $900 \mu \mathrm{m}$ diameter. Oocytes grew significantly during $\mathrm{OM}$, and at ovulation had a mean diameter of around $1500 \mu \mathrm{m}$ (Figure 4a). Due to the high variation between samples, female wreckfish $17 \beta$-estradiol $\left(E_{2}\right)$ concentration did not show statistically significant changes with the oocyte stage, although a trend of increasing values until vitellogenesis and decreasing values thereafter was visible (Figure $4 \mathrm{~b}$ ). Testosterone remained at low levels at the lipid vesicle and cortical alveoli stage, increased however during vitellogenesis. A second increase was observed during $\mathrm{OM}$, whereas a significant decrease was observed at ovulation (Figure 4c). Plasma 17,20ß-dihydroxy-progesterone (17,20ß-P) concentrations did not seem to change in respect to oocyte stage (Figure $4 \mathrm{~d}$ ). 


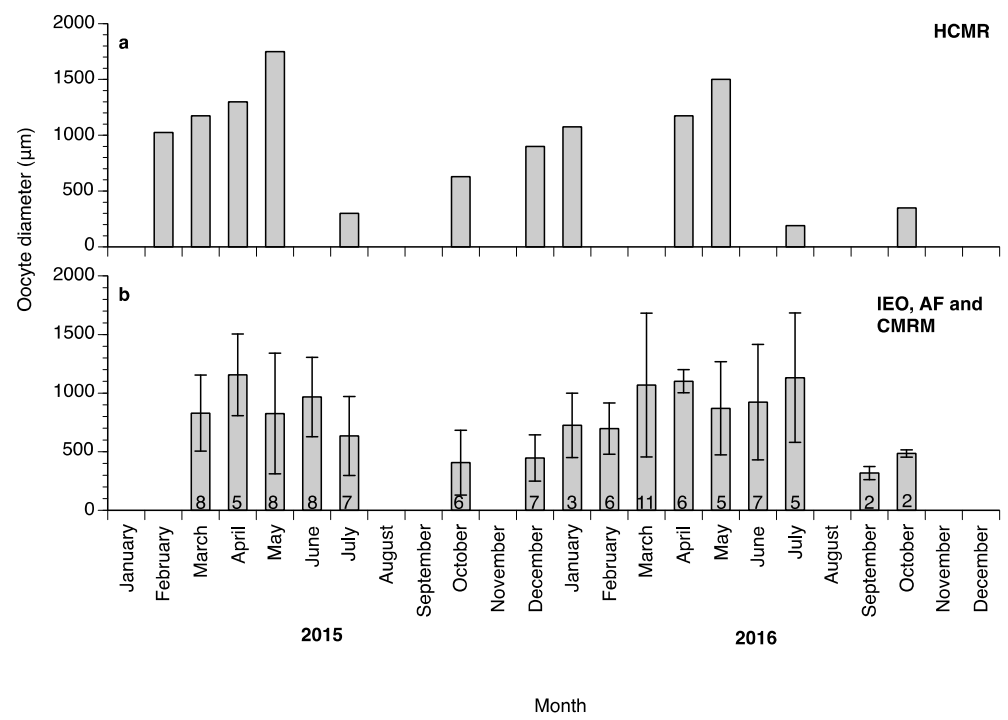

Figure 3. Mean ( \pm standard deviation (SD)) oocyte diameters of a wreckfish from the Hellenic Center for Marine Research (HCMR), Greece (a) and from three different broodstocks in Spain (b) during the annual reproductive cycles in 2015 and in 2016. The numbers inside the bars indicate the number of females biopsied at each month. IEO: Instituto Español de Oceanografía, AF: Aquarium Finisterrae, CMRM: Conselleria do Medio Rural e Mariño.

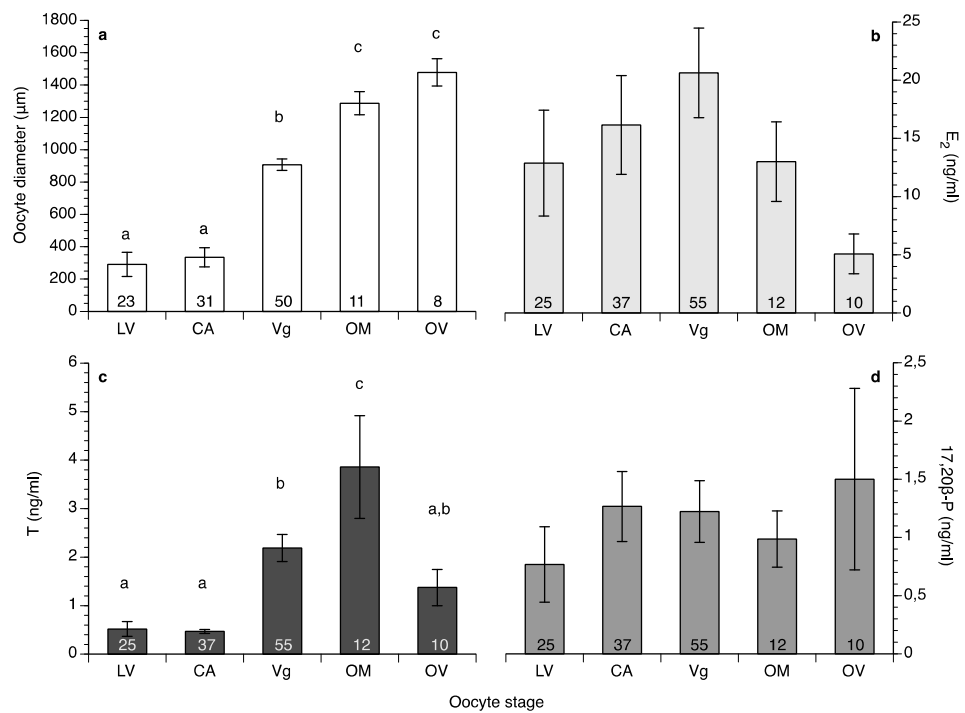

Figure 4. Mean ( \pm standard error of the mean (SEM)) oocyte diameter (a), concentrations of $17 \beta$-estradiol $\left(E_{2}\right),(\mathbf{b})$, testosterone $T,(\mathbf{c})$ and $17,20 \beta$-dihydroxy-progesterone $(17,20 \beta-P),(d)$ at different stages of oocyte development of wreckfish kept in captivity (LV: lipid vesicle, CA: cortical alveoli, Vg: vitellogenesis). Different letter superscripts indicate statistically significant differences among oocyte stages (one-way analysis of variance (ANOVA), Tukey's Honest Significant Difference (HSD) test, $p<0.05)$. The numbers inside the bars indicate the number of females sampled at each stage. The numbers inside the oocyte diameter bars represent the number of wet mount biopsies measured, whereas the numbers inside the sex steroid bars represent the number of females sampled, including those who were staged after histological processing of their biopsies.

Some spermiating males could be found all year round, with the percentages of fish with spermiation index of S0, S1, S2 or S3 varying between months (Figure 5a,b). The highest percentage of nonspermiating fish (S0) was found from September until December in Spain (Figure 5b), whereas a high percentage of spermiating fish (S2 and S3) was found from January until July during both years of the study both at HCMR and in Spain (Figure 5a,b). 
Sperm motility percentage was high $(>60 \%)$ during the study (Figure $6 a)$, whereas sperm motility duration varied between 1.5 and 6 min (Figure $6 \mathrm{~b}$ ). Sperm density values ranged between 4.5 and $18 \times 10^{9}$ spermatozoa $\mathrm{mL}^{-1}$ (Figure 7a) and sperm survival at $4{ }^{\circ} \mathrm{C}$ exhibited mean values of 3-13 days (Figure $7 \mathrm{~b}$ ). Sperm quality parameters were well correlated with the spermiation stage (index) of the fish, with S3 fish exhibiting higher spermatozoa motility percentage, motility duration and survival at $4{ }^{\circ} \mathrm{C}$ (Figure 8). Only sperm density was not related to the spermiation index (Figure 8).

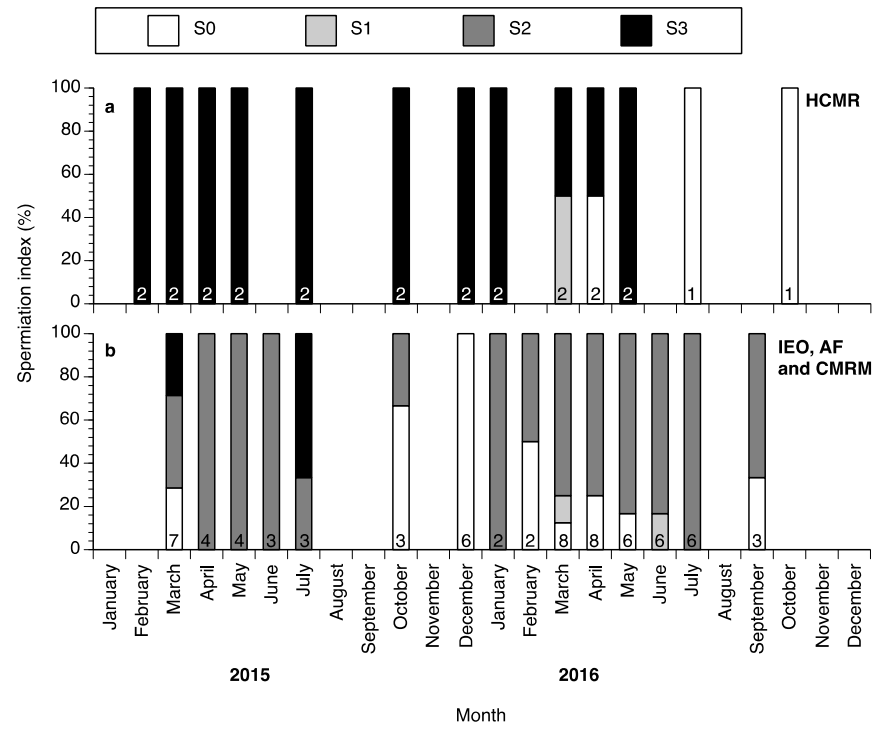

Figure 5. Male wreckfish at different spermiation index stages in HCMR, Greece (a) and in the three broodstocks in Spain (b) between February 2015 and October 2016. Spermiation index S0 = no milt released, S1 = only a drop of milt released after multiple stripping attempts, S2 = milt was released easily after the first stripping attempt and S3 = milt was fluently released even without abdominal pressure. The numbers inside the bars indicate the number of males examined each month.

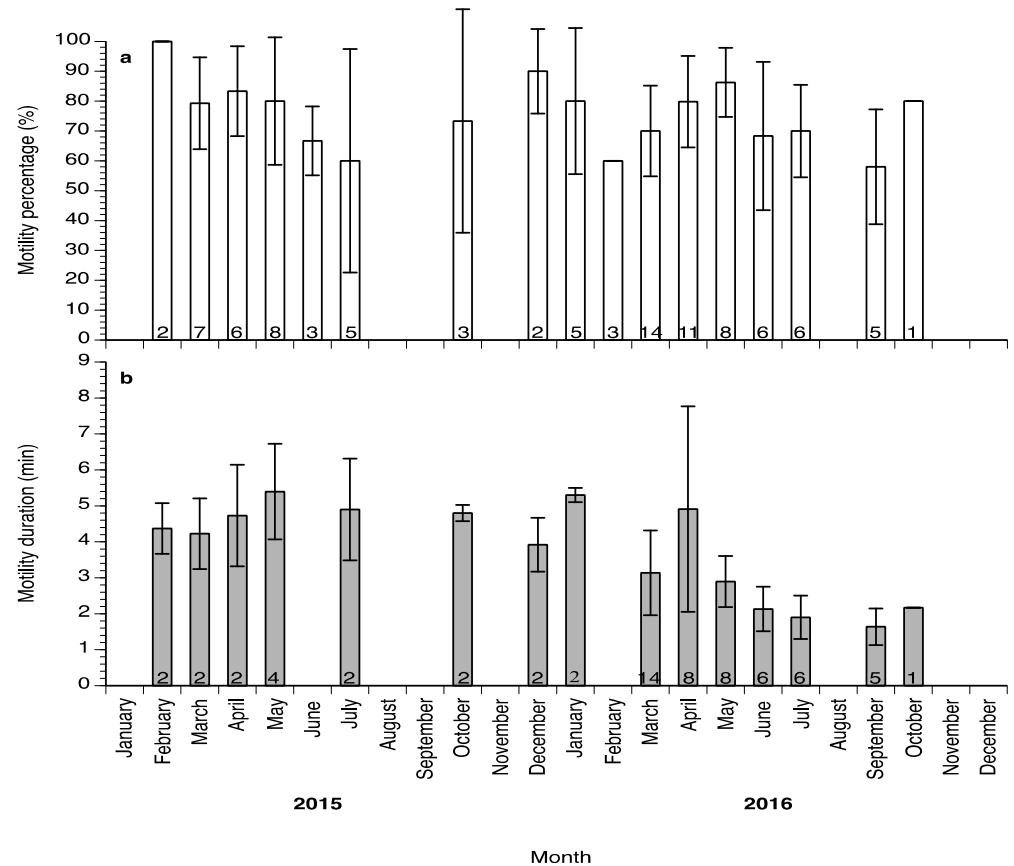

Figure 6. Mean $( \pm S D)$ sperm motility percentage (a) and sperm motility duration (b) of sperm collected from wreckfish between February 2015 and October 2016. Different numbers inside the bars indicate the number of sperm samples used for each sperm quality parameter. 

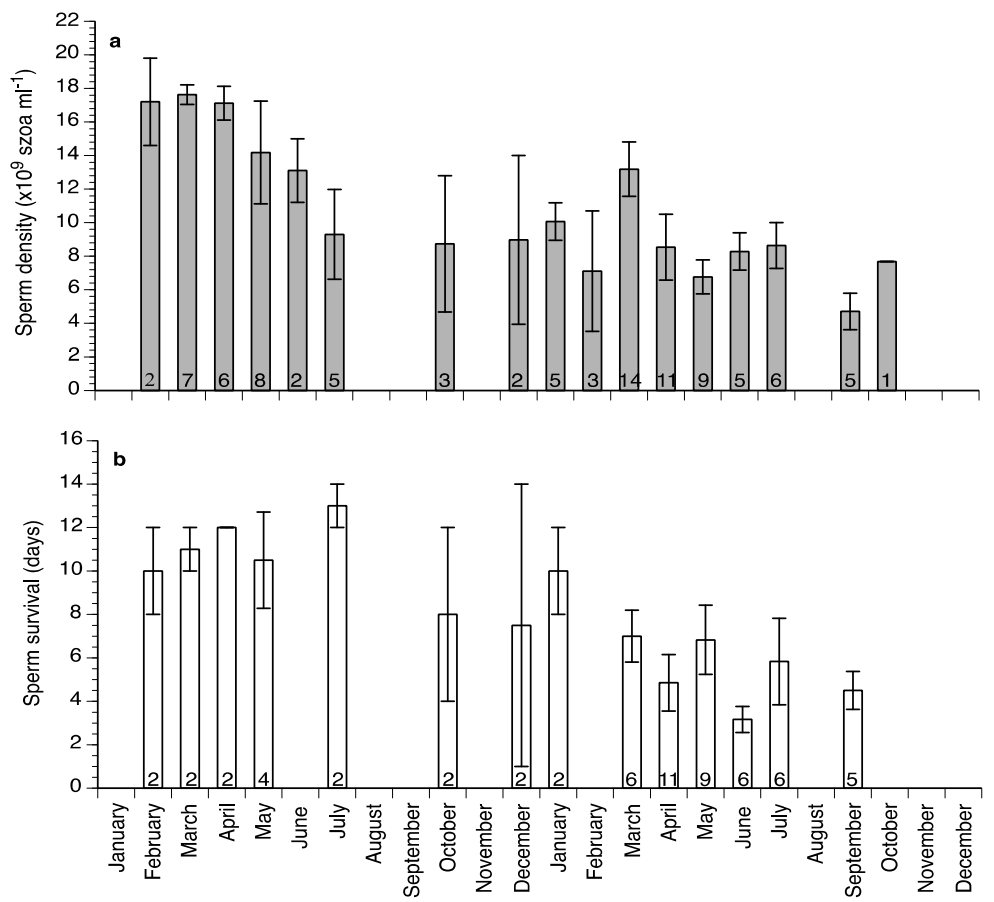

2015

2016

Month

Figure 7. Mean $( \pm \mathrm{SD})$ sperm density (a) and survival at $4{ }^{\circ} \mathrm{C}(\mathbf{b})$ of sperm collected from wreckfish between February 2015 and October 2016. Different numbers inside the bars indicate the number of sperm samples used.
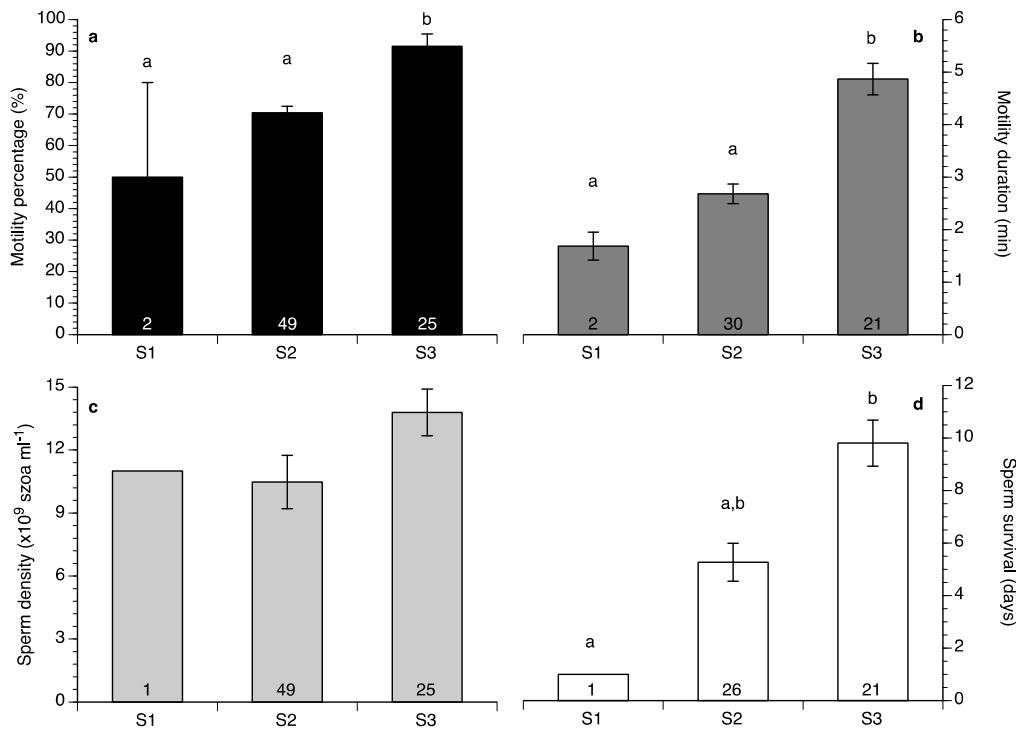

Spermiation index

Figure 8. Mean ( \pm SEM) sperm motility (a), duration (b), density (c) and survival at $4{ }^{\circ} \mathrm{C}(\mathbf{d})$ of four different broodstocks of wreckfish in Greece and Spain in relation to spermiation index (see Figure 5). Different letter superscripts indicate statistically significant differences among spermiation indexes, and numbers inside the bars indicate the number of males at each spermiation index (one-way ANOVA, Tukey's HSD test, $p<0.05$ ).

Testosterone (Figure 9a) and 11-ketotestosterone (11-KT) (Figure 9b) had low values in males with a spermiation index of S0 and reached their highest values at the S3 stage, whereas 17,20 $\beta$-P did not change significantly with spermiation index (Figure 9c). 

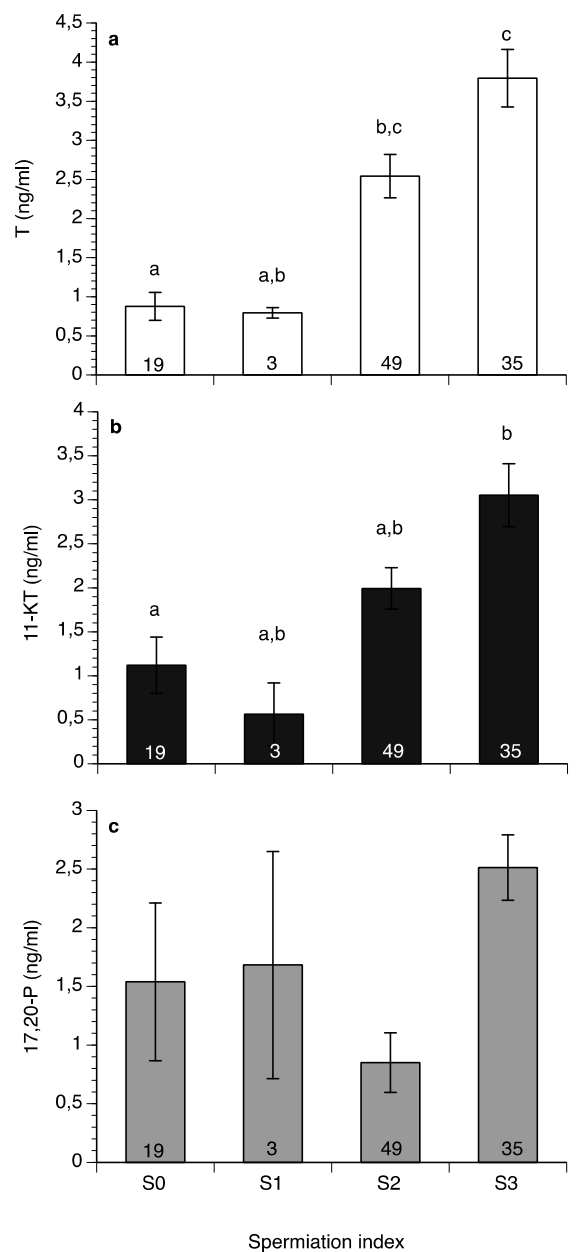

Figure 9. Mean ( \pm SEM) plasma testosterone (a), 11-ketotestosteone (11-KT) (b) and 17,20 3 -dihydroxy-progesterone (c) of wreckfish in relation to spermiation index (See Figure 5). Different letter superscripts indicate statistically significant differences among spermiation indexes, and numbers inside the bars indicate the number of males at each spermiation index stage (one-way ANOVA, Tukey's HSD test, $p<0.05)$.

Spontaneous spawns of captive wreckfish broodstocks were observed during 2015, 2016 and 2017 (Figure 10). In 2015, 23 spawns with very low fertilization percentage were observed at HCMR in April and May, 7 spawns from March until April at IEO, and 11 spawns from May until June at the Aquarium Finisterrae (AF). During 2016, from February to the end of May, 12 spawns were obtained at HCMR, 8 at IEO, and 16 at AF. In 2017, spawning lasted from March until May and spontaneous spawns were also achieved at the CMRM broodstock, showing very high fertilization percentages (Figure 10c). Eighteen spontaneous spawns were observed at HCMR, 11 at IEO and 10 at CMRM. In 2018, 42 natural spawns were observed at IEO, with mean fecundity values of 130,000 eggs per female (data not shown). Relative fecundity and fertilization varied considerably, with fertilization exhibiting values from 0 to 100\% (Figure 10), whereas in 2017 fertilization success improved greatly. In 2015 and 2016, even when fecundity values were high, fertilization was often null or close to zero. Individual female wreckfish were observed to spawn every $4-5$ days. 


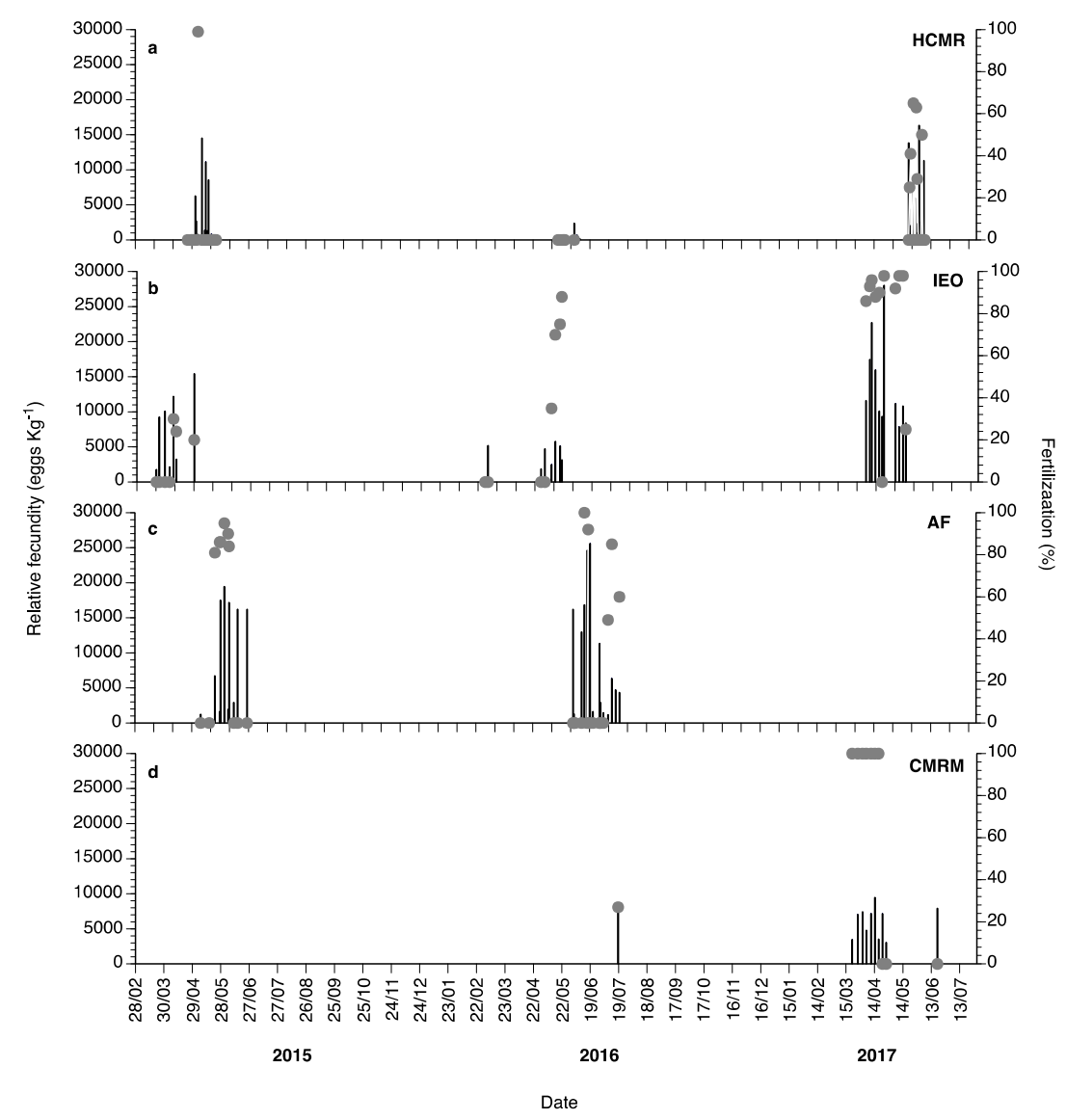

Figure 10. Mean relative fecundity (black bars) and fertilization (\%, grey circles) of the spontaneous spawns of wreckfish broodstocks obtained at HCMR (a), Instituto Español de Oceanografía (IEO) (b), Aquarium Finisterrae (AF) (c) and Conselleria do Medio Rural e Mariño (CMRM) (d) during 2015, 2016 and 2017.

\section{Discussion}

The reproductive period (oogenesis, maturation, and spawning) was rather extended in wreckfish, and not constant between different stocks, beginning in October and, in the Spanish broodstocks that were exposed to lower temperatures during the year, lasting until July. The highest oocyte diameter of wreckfish oocytes was found between March and July, defining this to be its maturation and spawning period, in contrast to a study in the Ionian Sea, Greece, where spawning was considered to occur in the autumn-winter season [22], but in accordance with other studies, where attempts were made for spawning induction in May $[9,23,24]$. The spawning period of wreckfish in the southern hemisphere was reported to occur in the austral winter, from July until October [4], and coincides with the spawning period of the congener hāpuku [25]. Wreckfish oocytes remained unchanged in size during the progression from the lipid vesicle to the cortical alveoli stage and increased dramatically in size during vitellogenesis, when they reached $>1000 \mu \mathrm{m}$, as reported both in other studies of captive breeders [9,26] as well as fish from the wild [4]. Spawned eggs were around $2 \mathrm{~mm}$ in diameter and had from one to multiple oil globules [9], as has also been shown for the hāpuku [6]. The egg size of wreckfish [4] is markedly larger than any other marine fish cultured in the temperate waters of the Atlantic coast of Europe and the Mediterranean Sea. A large egg size and lower fecundity is considered essential for demersal fishes, such as flatfishes, as it is related to higher individual survival in a relatively constant environment; in contrast, pelagic small eggs have to face a changing environment where survival is more difficult and thus high fecundity is more advantageous [27]. For comparison, in pelagic fishes, mean egg diameter is $1.02 \mathrm{~mm}$ in the red porgy Pagrus pagrus [28], $1.03 \mathrm{~mm}$ in greater amberjack [13] and $1.15 \mathrm{~mm}$ in European sea bass Dicentrarchus labrax [29]. On the contrary, egg 
diameter in flatfishes ranges between 1.8-2 mm in the plaice Pleuronectes platessa [30] and 2.9-3.3 mm in the Atlantic halibut Hippoglossus hippoglossus [31]. Thus, the wreckfish, similar to the congener hāpuku [6], being a deep-sea demersal species, seems to have followed this evolutionary trend in egg diameter, even though the eggs are positively buoyant [23] and most probably are transported to shallow waters soon after spawning, where larvae and juveniles are usually found during their pelagic stage [2,32]. A larger egg and yolk size may be a considerable advantage for any aquaculture species, since it means that the prelarval stage (i.e., autotrophic) will be long and at the time of first feeding the larvae will have a larger body and mouth size, potentially being able to accept larger feed items and having a better developed visual and digestive system [33,34], enabling them to perform better under aquaculture conditions.

Although most of the females managed to proceed with oogenesis and did reach maturation, in Spain four females from IEO and two females from CMRM did not progress beyond the cortical alveoli stage and their oocytes did not increase in diameter more than $350 \mu \mathrm{m}$. This phenomenon occurred during both years of the study in the same females. Normally, the cortical alveoli stage defines the early developing ovary [35]. However, in some fish species, such as the common wolffish Anarhichas minorin and the spotted wolffish Anarhichas lupus, ovaries can maintain the cortical alveoli oocyte developmental stage for up to nine years before maturation and first spawning [36,37]. Other species may be able to have cortical alveoli oocytes in their ovaries when immature, such as the Greenland halibut Reinhardtius hippoglossoides [38]. The specific wreckfish females of the present study (CMRM and IEO) were all captured in 2009 at average sizes of 1 and $7 \mathrm{~kg}$, respectively, so it cannot be certain whether they were able to mature at nearly 5-6 and 10 years of age. Whereas first maturation of wreckfish in the wild occurs at 10 years for females and 9 years for males in the southwestern Atlantic Ocean [4], in the northwestern Ionian Sea it has been found to occur at an earlier age (7-8 years) with the youngest individuals maturing at 5 and 4 years for females and males, respectively [22]. Maturation at 5 years of age was also observed in F1 female hāpuku in New Zealand [8]. In the present study, out of a total of 31 fish, these six females arrested oocyte development at the cortical alveoli stage, remaining at this stage for almost two years. In 2018 (not part of the present study) this arrest of oocyte development was overcome, with almost all females in the specific stock in Spain (IEO) being able to spawn. In some F1 generation females of the hāpuku, early vitellogenesis was reached with oocyte diameter $<0.4 \mathrm{~mm}$. However, since the females then exhibited degenerating oocytes, this was considered to be a dummy run [8]. From the above, it may be inferred that the specific female wreckfish of the present study either remained immature at the cortical alveoli stage or skipped spawning by arresting oocyte development at the specific oocyte stage, a phenomenon which has received increased attention in recent years and has been demonstrated in several species studied in the wild $[39,40]$. Skipped spawning, which has been reported in natural fish populations, has been attributed mainly to poor nutrition during the spawning period and it can occur mostly in smaller females that do not migrate to the spawning grounds, but stay at the feeding grounds for energy conservation $[39,41]$.

A constant low temperature of $16^{\circ} \mathrm{C}$ did not seem to have any beneficial effect on the reproductive development of captive female wreckfish, although it is probably more representative of the natural deep-water environment of wreckfish breeders, since fish held in the naturally fluctuating temperatures in northwestern Spain exhibited the same or even better reproductive performance than fish under constant temperature, that is, they matured and spawned spontaneously. Low temperature is preferred by wreckfish in captivity, as loss of appetite and growth cessation were observed at temperatures $>20{ }^{\circ} \mathrm{C}$ [5]; the same holds true for the hāpuku, as it was shown that fish over $1 \mathrm{~kg}$ in body weight grow better at 18 than at $22{ }^{\circ} \mathrm{C}$ [42]. Hāpuku broodstocks in New Zealand were maintained at fluctuating temperatures of $10-19{ }^{\circ} \mathrm{C}$ during the non-reproductive season and at 10 or $13.5^{\circ} \mathrm{C}$ during the reproductive season $[7,8]$. Based on the findings of the present study, as well as that of Fauvel et al. [9], broodstock management of wreckfish in aquaculture could be carried out either in constant low or annually cycling water temperatures (typical of the northwestern coast of Spain) according to what is more available for the hatchery, without any apparent negative influence on the reproductive 
process. However, although several different breeders at HCMR have been kept over a period of more than 15 years under constant low temperature, exhibiting the same reproductive performance through the years (Fauvel et al. [9] and unpublished data), any conclusions based on this broodstock should be interpreted with caution, due to the small number of fish consisting it.

The endocrine control of oogenesis already described in a large number of fishes has provided important practical information on monitoring the reproductive function in aquaculture $[43,44]$. Vitellogenesis begins with an increase in the follicle-stimulating hormone (FSH), which leads to an increase in oestradiol $\left(\mathrm{E}_{2}\right)$ [45]. During vitellogenesis, testosterone $(\mathrm{T})$ is produced in the theca cells of the ovarian follicles and converted to $E_{2}$ in the granulosa cells; $E_{2}$ then promotes vitellogenin synthesis in the liver. After vitellogenesis, $\mathrm{E}_{2}$ drops and $\mathrm{T}$ increases during germinal vesicle migration; at that time, the luteinizing hormone $(\mathrm{LH})$ induces oocyte maturation $(\mathrm{OM})$ through the synthesis of the maturation inducing steroid (MIS), which is usually $17,20 \beta$-P or 17,20 $\beta, 21$-trihydroxy-pregnen-3-one $(17,20 \beta, 21-P)[46,47]$. The pattern of sex steroid changes in relation to the stage of oocyte development in wreckfish followed the above-mentioned biochemical cascade. In particular, T was low prior to the onset of vitellogenesis, increased as oogenesis proceeded, and decreased when females had ovulated eggs. At the same time, $E_{2}$ showed a similar pattern of gradually increasing plasma levels during oogenesis and declining levels once postvitellogenic and maturing oocytes began to be present in the ovaries. On the other hand, plasma 17,20 $\beta$-P levels were significantly lower than the other sex steroids and remained unchanged throughout oocyte development and maturation. Recent studies in different fish species support the involvement of $\mathrm{T}$ in $\mathrm{OM}$, and the existence of low levels of both $\mathrm{T}$ and $\mathrm{E}_{2}$ at the time of ovulation. For example, $\mathrm{T}$ induced $\mathrm{OM}$, in terms of germinal vesicle breakdown, but not ovulation when administered in vivo to zebrafish Danio rerio oocytes [48]. Moreover, estrogen-synthesizing genes were down regulated in the preovulatory period of the rainbow trout Oncorhynchus mykiss [49]. Low and relatively stable levels of 17,20ß-P may reflect rapid catabolism of the hormone or transformation to conjugated forms $[14,46]$, or may indicate that this steroid is not the actual MIS for wreckfish, as has been suggested for Atlantic cod and yellowfin porgy Acanthopagrus latus $[50,51]$. More frequent samplings around the time of $\mathrm{OM}$, as well as examination of the presence of conjugated steroids at this time will be necessary to better define the nature and role of progestogens in the process of OM in wreckfish.

Although the highest number of spermiating wreckfish in the present study was observed between March and July, covering the spawning period of the females, some spermiating males were present throughout the year in all studied broodstocks. It is not known if this is a natural phenomenon or something observed under captive conditions. Provided that year-round spermiation does not cause any negative effects on the welfare of the fish or the quality of the sperm, this can be a very useful characteristic for aquaculturists, especially for the development of cryopreservation protocols and artificial insemination practices. Males spermiating all year round have also been found in the Senegalese sole, a species able to reproduce at least at two different periods during the year [52].

All studied sperm quality parameters varied significantly during the two years of the study, but without any clear correlation with the female breeding season (March-June). Overall, sperm quality was considered high throughout the year. Mean sperm density ranged between $4.5-18 \times 10^{9}$ spermatozoa $\mathrm{mL}^{-1}$, sperm motility was always higher than $60 \%$, motility duration ranged between 1.5 and $6 \mathrm{~min}$ and survival of sperm at $4{ }^{\circ} \mathrm{C}$ ranged between 3 and 13 days. To the best of our knowledge, this is the first study that reports on sperm quality of the wreckfish; consequently, since no study has been conducted on its congener, the hāpuku, there are no other data from this genus with which to compare the results of the present study. However, the mean values observed fall within the values already reported for other marine fish species [53]. For example, mean density has been found

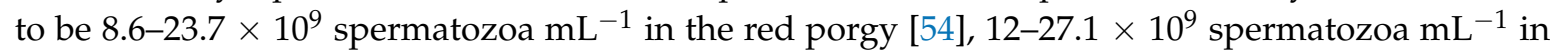
the sharpsnout seabream [55], 18.9-31.5 $\times 10^{9}$ spermatozoa $\mathrm{mL}^{-1}$ in the meagre [15], $23-46 \times 10^{9}$ spermatozoa $\mathrm{mL}^{-1}$ in the greater amberjack [56] and $38 \times 10^{9}$ spermatozoa $\mathrm{mL}^{-1}$ in the Atlantic bluefin tuna Thunnus thynnus [57]. Similarly, motility duration ranged between 2-4 min in the red 
porgy [54], 2-6 $\mathrm{min}$ in the sharpsnout seabream [55], 0.78-1.27 in the meagre [15] and 10-11 $\mathrm{min}$ in the Atlantic bluefin tuna [57]. Therefore, since the sperm quality of wreckfish males maintained in captivity can be considered good, with no noticeable dysfunction involved, either in the quality or in the quantity of sperm produced, it is not anticipated that this would constitute a bottleneck in the broodstock management of this species under aquaculture conditions. Sperm quality parameters did show a significant correlation with the stage of spermiation, with spermatozoa motility percentage and duration, as well as survival of spermatozoa during storage showing significant increases in fish progressing from stage S1 to S3. Nevertheless, spermatozoa density was not related to spermiation stage, which means that as more sperm or milt is produced, more spermatozoa are also produced, maintaining the same spermatozoa density in the milt. These results suggest that this subjective method for evaluating spermiation, which is based on the ease of sperm collection upon application of gentle abdominal pressure, is a reliable method for predicting the quality of sperm in wreckfish. The ease of sperm collection and the higher spermiation index is probably due to increases in the volume of sperm produced, so it is reasonable to conclude that with the increase of spermiation (release of spermatozoa from the spermatocysts) and seminal fluid production, there is also an improvement in the quality characteristics of the sperm. This information may be useful for sperm management in aquaculture.

In male fish, spermatogenesis is controlled by the two gonadotrophic hormones, FSH and LH [58]. The FSH acts on the Leydig cells to stimulate androgen production, whereas LH acts on the Sertoli cells to support germ cell survival and development [59]. Androgens then act on the gonads; $\mathrm{T}$ has been associated with spermatogenesis and 11-KT with spermiation, with 11-KT being the most effective androgen in teleosts [60]. In the present study, both $\mathrm{T}$ and 11-KT were found to reach their highest values at late stages of spermiation (S3 spermiation index), as in cod, where higher $\mathrm{T}$ and 11-KT levels were observed concomitantly with the presence of free spermatozoa in the testis lumen [61], but unlike the Senegalese sole, which was found to exhibit the highest $\mathrm{T}$ and 11-KT values at late spermatogenesis and not at functional maturation [62]. On the other hand, as in females, plasma 17,20ß-P was relatively low at all stages of spermiation. The unchanged $17,20 \beta-P$ values in male wreckfish could mean that this hormone is maintained constantly at relatively low levels in fish that are producing sperm all year round, as also occurred with the Senegalese sole, which shows relatively constant $17,20 \beta$-P values [62]. Moreover, it has been suggested that $17,20 \beta, 21-\mathrm{P}$ is the MIS in most males of marine fishes, in contrast to freshwater species, for which 17,20 $\beta$-P is the effective MIS [58].

Wreckfish spawning events in the present study were scarce and inconsistent in almost all broodstocks, and with relatively low fertilization in 2015 and 2016, significantly lower than reported both for wild captive-reared [6] and F1 hatchery-produced hāpuku [7]. One puzzling observation was the frequent production of eggs with $0 \%$ fertilization in the present study. This may be explained either by a failure of males to release sperm when the females spawn, or by a delayed release of overripe eggs by the female. In the case of wreckfish, we believe the problem concerns male breeding behavior and lack of sperm release, since the produced eggs appeared to be morphologically normal. A similar dysfunction was observed with F1 males of the Senegalese sole, where females spawn viable eggs, but the males do not exhibit any breeding behavior and do not release sperm [63-65]. Relative batch fecundity was also variable among the four wreckfish broodstocks in the present study, varying between 2000 and 30,000 eggs spawn ${ }^{-1} \mathrm{~kg}^{-1}$ body weight. Similar values have been reported for cultured hāpuku, which produced an estimated 6500-18,000 eggs ${ }^{-1}$ spawn $^{-1}$ female $^{-1}[6,7,66]$ and between 690,000 and 1,250,000 eggs female ${ }^{-1}$ year $^{-1}[6,7,66]$, assuming that all females in the broodstock had spawned. Using histological methods (number of vitellogenic oocytes) the maximum ovarian fecundity in wild wreckfish has been estimated to be from 3 to 11.9 million eggs female ${ }^{-1}$ year $^{-1}$ [4]. Spawning frequency in the present study was about every $4-5$ days, and this was also consistent among the different broodstocks, regardless of water temperature conditions.

Spawning was more consistent in 2017, perhaps as breeders had more time to acclimatize to captivity and produced more spawns with improved fertilization percentages. Furthermore, during 
the 2018 reproductive season (not included in the present study) spawning seemed to be even more consistent with even better fecundity and fertilization in the Spanish broodstocks. Based on the results presented here, it can be anticipated that full acclimatization of the species to captivity conditions will eventually come with time, and consistent natural spawning and production of good-quality eggs will be achieved. Further work should focus on the improvement of the environmental conditions in captivity to ensure not only proper gametogenesis and maturation in males and females, but also proper breeding behavior and spawning. In addition, formulation of specific broodstock diets is also essential, as has also been done for the hāpuku [7], and efforts are on the way to define the nutritional requirements of breeders based on the body and gonad composition of mature wild fish $[67,68]$.

\section{Materials and Methods}

\subsection{Broodstock Maintenance}

Four different broodstocks with variable number of breeders collected from the wild were maintained in research facilities in Greece and Spain. Fish were collected from the wild at the early juvenile stage (HCMR) using fish aggregating devices, or as subadults prior to diving to deep waters, by hook and line (Spanish stocks). The facilities used for maintaining the broodstocks were the HCMR $(n=3)$ in Heraklion, Crete, Greece; the IEO $(n=13)$ in Vigo, Spain; the Aquarium Finisterrae (AF, $n=21)$ in A Coruña, Spain; and the CMRM $(n=11)$ in Pontevedra, Spain. At HCMR, one female and two males having a mean weight \pm standard deviation (SD) 13.1 and $9.08 \pm 2.66 \mathrm{~kg}$ respectively, were kept in a $15-\mathrm{m}^{3}$ tank, under simulated natural photoperiod and constant low temperature of around $16{ }^{\circ} \mathrm{C}$, to approach the deep-water conditions in the Mediterranean. On 12 June 2016 one of the males died, leaving the broodstock of HCMR with just one female and one male. At IEO, ten females and three males of $16.2 \pm 4.05$ and $11.6 \pm 1.59 \mathrm{~kg}$ respectively, were kept in two $110-\mathrm{m}^{3}$ tanks under natural photoperiod and water temperature. At AF, 12 females and nine males of $23.1 \pm 6.8$ and $17.4 \pm 3.3 \mathrm{~kg}$, respectively, were kept in a large exhibition tank of $3500 \mathrm{~m}^{3}$ and in the breeder's tank of $33 \mathrm{~m}^{3}$ under simulated natural photoperiod and natural water temperature. Finally, at CMRM eight females and three males of $14.4 \pm 2.8$ and $13.3 \pm 0.55 \mathrm{~kg}$, respectively, were kept in two tanks of 120 and $180 \mathrm{~m}^{3}$ under natural photoperiod and water temperature. On 15 August 2016 one female fish died from the CMRM broodstock. Apart from the HCMR broodstock, the other three stocks were maintained in relatively similar temperature conditions, which were ambient for the northwestern coast of Spain (Figure 11). For egg collection, a passive egg collector was placed in the outflow of the tank, to verify the occurrence of any spawning and collect the spawned eggs.

Fish were fed three times per week with frozen fish at HCMR, and oxygen, temperature, and water quality $\left(\mathrm{NH}_{3}-\mathrm{N}\right.$ and $\left.\mathrm{NO}_{2}-\mathrm{N}\right)$ were measured once per week. At IEO, one broodstock was fed three times per week with semi-moist pellets and the other one with a specific formulation according to the fish's biochemical profile [67]. At CMRM, commercial dry food was used three times per week, Vitalis Repro during the resting period and Vitalis Cal from November 2014 until the end of March 2015 (Skretting, Verona, Italy). At AF, wreckfish broodstock was fed a mixture of semimoist diet and fresh fish, three times per week. Temperature and oxygen were measured every day. Natural water temperature and natural photoperiod were used in all Spanish broodstocks.

At HCMR when spawning was observed, eggs from the tank egg collectors were transferred into a 10-L bucket using a dip net and their number (fecundity) was estimated by counting the total number of eggs in a subsample of $10 \mathrm{~mL}$, after vigorous agitation. Fertilization success was evaluated at the same time by calculating the number of viable eggs with respect to the total number of eggs spawned. At IEO, CMRM and AF, eggs were transferred into a graduated cylinder and the volume $(\mathrm{mL})$ of the total number of eggs spawned and of floating eggs was determined. Then, fertilization success was estimated in a subsample of the floating eggs using a stereoscope. The total number of eggs spawned was estimated by multiplying the observed egg volume by 150, which is the mean number of wreckfish eggs found in $1 \mathrm{~mL}$ of seawater. 


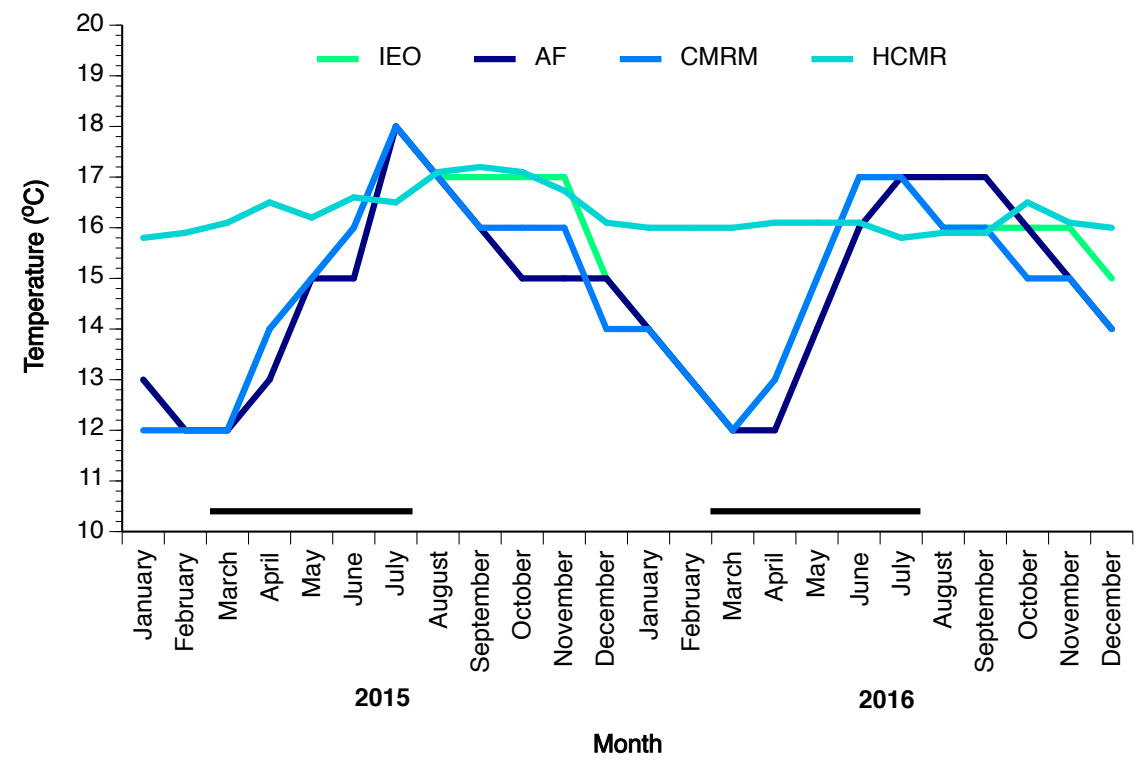

Figure 11. Tank water temperature $\left({ }^{\circ} \mathrm{C}\right)$ of wreckfish broodstocks at four different sites: at the Hellenic Center for Marine Research (HCMR) in Greece, and at the Instituto Español de Oceanografía (IEO), the Aquarium Finisterrae (AF) and the Conselleria do Medio Rural e Mariño (CMRM) in Spain from January 2015 until December 2016. The temperature line of IEO overlaps with CMRM when not visible.

The experimental protocol was approved by the National Veterinary Services (AP 255356). All procedures involving animals were conducted in accordance to the "Guidelines for the treatment of animals in behavioral research and teaching" [69], the Ethical justification for the use and treatment of fishes in research: an update [70] and the "Directive 2010/63/EU of the European parliament and the council of 22 September 2010 on the protection of animals used for scientific purposes" [71].

\subsection{Samplings}

Fish were monitored for their stage of reproductive development between March 2015 and October 2016, encompassing two spawning seasons (2015 and 2016) and one complete reproductive season. Samplings were conducted monthly from February until June and bimonthly from July until January. At each sampling, fish were tranquilized initially in their rearing tank with the use of clove oil $\left(0.01 \mathrm{~mL} \mathrm{~L}^{-1}\right)$ and then transferred to an anesthetic bath for complete sedation with a higher concentration of clove oil $\left(0.03 \mathrm{~mL} \mathrm{~L}^{-1}\right)$ [72]. After measuring total length and wet weight, ovarian biopsies for the evaluation of oocyte development were obtained with the use of a Pipelle de Cornier catheter. A wet mount of the biopsy was examined under a compound microscope $(40 \times$ and $100 \times)$ to evaluate the stage of oogenesis and measure the mean diameter of the largest, most advanced oocytes $(n=10)$. A portion of the biopsy was fixed in a solution of $4 \%$ formaldehyde- $1 \%$ glutaraldehyde for further histological processing. Females that did not show any sign of OM for the duration of the study were excluded from the analysis of oocyte diameter in relation to month.

Maturation of the males was examined by the release of sperm upon application of gentle abdominal pressure. Sperm was collected after rinsing the fish with clean seawater and blot drying the genital pore. Small volumes of sperm $(50-100 \mu \mathrm{L})$ were collected to avoid influencing the quantity and/or quality of sperm during subsequent collections. The collected sperm was stored on ice and then transferred to a $4{ }^{\circ} \mathrm{C}$ refrigerator until evaluation. Spermiation index was evaluated based on the presence and ease of milt release upon the application of gentle abdominal pressure [54]. Spermiation index was reported on a subjective scale from 0 to 3 , with $\mathrm{S} 0=$ no milt released, $\mathrm{S} 1=$ only a drop of milt released after multiple stripping attempts, $\mathrm{S} 2=$ milt was released easily after the first stripping attempt and S3 = milt was fluently released even without abdominal pressure. Sperm quality parameters that were evaluated included sperm concentration (number of spermatozoa $\mathrm{mL}^{-1}$ of milt), percentage of 
spermatozoa showing forward motility immediately after activation (initial sperm motility, \%) and duration of forward sperm motility of at least $10 \%$ of the spermatozoa in the field of view (motility duration, min). Sperm concentration was estimated after a 2121-fold dilution with seawater using a Neubauer hemocytometer (Hirschmann, Eberstadt, Germany) under 200× magnification (in duplicate) in a compound light microscope (Nikon, Eclipse 50i, Tokyo, Japan). Sperm motility and motility duration were evaluated on a microscope slide (400× magnification), after mixing $1 \mu \mathrm{L}$ of sperm with a drop of about $50 \mu \mathrm{L}$ of seawater (in duplicate). Males that did not show any sign of maturation (i.e., did not produce sperm for the duration of the study) were excluded from the analysis.

Blood was collected from all fish at each sampling, to measure sex steroid hormone concentrations. Blood was centrifuged at $6000 \mathrm{rpm}$ for $15 \mathrm{~min}$ and the collected plasma was stored at $-80{ }^{\circ} \mathrm{C}$ until analysis. Due to a mistake during the March 2015 sampling in IEO, CMRM and AF, samples of this month were excluded from the plasma sex steroid analysis.

\subsection{Histological Processing}

Before embedding in methacrylate resin (Technovit $7100^{\circledR}$, Heraeus Kulzer, Hanau, Germany) ovarian biopsies were dehydrated in gradually increasing ethanol solutions (70-96\%). Serial sections of $4 \mu \mathrm{m}$ were obtained with a microtome (Leica, RM 2245, Nussloch, Germany). Sections were stained with methylene blue (Sigma-Aldrich, Steinheim, Germany)/Azure II (Sigma-Aldrich, Steinheim, Germany)/Basic Fuchsin (Polysciences, Warrington, PA, USA) according to [73], they were examined under a light compound microscope (Nikon Eclipse 50i, Tokyo, Japan) and photographed with a digital camera (Jenoptik Progres C12 Plus, Jena, Germany).

\subsection{Hormone Measurements}

For the quantification of $\mathrm{T}, \mathrm{E}_{2}, 11-\mathrm{KT}$ and $17,20 \beta-\mathrm{P}$ in the plasma, already established and well-described enzyme-linked immunoassays (ELISA) were used [74-76] with some modifications, using reagents from Cayman Chemical Company (Ann Arbor, MI, USA). For steroid extraction, $200 \mu \mathrm{L}$ of plasma were extracted twice with $2 \mathrm{~mL}$ diethyl ether. Extraction was done by vigorous vortexing (Vibramax 110, Heidolph, Schwabach, Germany) for $3 \mathrm{~min}$. After decanting of the organic phase, drying of the supernatant was done under a stream of nitrogen (Reacti-vap III, Pierce, Rockford, IL, USA). Samples were reconstituted in reaction buffer for running in the ELISA.

\subsection{Statistical Analysis}

Perhaps due to differences in the geographic origin of the wild-captured fish, the holding location of the four stocks (Greece vs. Spain), as well as rearing conditions (constant vs. ambient temperatures), there was a wide variation in the timing of gametogenesis. As a result, the data obtained during the year exhibited a high standard error. Therefore, differences in mean oocyte diameter, and sperm motility, duration, density, and survival between months, were not analyzed statistically, but are presented as means $\pm \mathrm{SD}$.

The data were also categorized according to stage of development. Differences in oocyte diameter and steroid hormone concentrations in relation to oocyte stage, as well as differences in sperm quality parameters and steroid hormone concentrations in relation to spermiation index were assessed with the use of one-way analysis of variance, followed by Tukey's Honest Significant Difference (HSD) test, at a minimum significance of $p<0.05$. Unless otherwise mentioned, results are presented as mean \pm standard error of the mean (SEM). Statistical analyses were performed using the statistical software JMP (SAS Institute Inc., Cary, NC, USA).

\section{Conclusions}

The results of the present study showed that wreckfish females could adapt to captivity, mature, and produce eggs, with a frequency of every $4-5$ days when maintained either at constant low water temperature or at fluctuating temperatures typical of the northwestern coast of Spain. However, more 
efforts are needed towards the understanding of the optimal environmental conditions under which wreckfish broodstocks should be kept but perhaps also the definition of appropriate diets, to achieve a better spawning performance of this deep-water species. The female reproductive dysfunctions that were identified included: (a) the arrest of oogenesis at the cortical alveoli stage in certain females; (b) the failure to undergo OM in others; and (c) the production of large percentages of unfertilized eggs from the females that spawned spontaneously. Males, on the other hand, produced sperm of good quantity and quality all year round, rendering it available to fish farmers for cryopreservation and artificial fertilization whenever it is needed, although breeding behavior may be problematic, resulting in very low or zero fertilization success. Plasma sex steroid hormones in males and females correlated well with maturity stages, while plasma 17,20ß-P remained low and unchanged throughout the year.

Author Contributions: Conceptualization, C.C.M., J.B.P., and F.L.; Methodology, C.C.M., J.B.P. and F.L.; Software, M.P., I.F.; Validation, C.C.M., J.B.P., B.A.-B. and F.L.; Formal Analysis, M.P., I.F., C.C.M.; Investigation, M.P., I.F., I.S., J.L.R.V., E.P.R., N.L., C.C.M., J.B.P., B.A.-B., A.V. and F.L.; Resources, C.C.M., J.B.P., B.A.-B., F.L. and A.V.; Data Curation, M.P., I.F., A.V., J.B.P., B.A.-B. and F.L.; Writing-Original Draft Preparation, M.P.; Writing-Review and Editing, M.P., I.F., C.C.M., J.B.P., B.A.-B., A.V. and F.L.; Visualization, M.P., I.F., C.C.M.; Supervision, C.C.M.; Project Administration, C.C.M., J.B.P., B.A.-B., A.V. and F.L.; Funding Acquisition, C.C.M., J.B.P., A.V. and F.L.

Funding: This research was funded by the EU 7th FP project DIVERSIFY (KBBE-2013-07 single stage, GA 603121) titled "Exploring the biological and socio-economic potential of new/emerging fish species for the expansion of the European aquaculture industry" awarded to C.C.M., J.B.P., F.L. and A.V.

Acknowledgments: We would like to acknowledge Pascal Divanach and Nikos Papandroulakis for the acquisition of wreckfish juveniles and adults for the creation of the captive broodstock of HCMR.

Conflicts of Interest: The authors declare no conflict of interest.

\section{References}

1. Machias, A.; Somarakis, S.; Papandroulakis, N.; Spedicato, M.-T.; Suquet, M.; Lembo, G.; Divanach, P. Settlement of the wreckfish (Polyprion americanus). Mar. Biol. 2003, 142, 45-52. [CrossRef]

2. Roberts, C.D. Reproductive mode in the percomorph fish genus Polyprion Oken. J. Fish Biol. 1989, 34, 1-9. [CrossRef]

3. Ball, A.O.; Sedberry, G.R.; Zatcoff, M.S.; Chapman, R.W.; Carlin, J.L. Population structure of wreckfish Polyprion americanus determined with microsatelite genetic markers. Mar. Biol. 2000, 137, 1077-1090. [CrossRef]

4. Peres, M.B.; Klippel, S. Reproductive biology of southwestern Atlantic wreckfish, Polyprion americanus (Teleostei: Polyprionidae). Environ. Biol. Fishes 2003, 68, 163-173. [CrossRef]

5. Papandroulakis, N.; Suquet, M.; Spedicato, M.T.; Machias, A.; Fauvel, C.; Divanach, P. Feeding rates, growth performance and gametogenesis of wreckfish (Polyprion americanus) kept in captivity. Aquacult. Int. 2004, 12, 395-407. [CrossRef]

6. Anderson, S.A.; Salinas, I.; Walker, S.P.; Gublin, Y.; Pether, S.; Kohn, Y.Y.; Symonds, J.E. Early development of New Zealand hapuku Polyprion oxygeneios eggs and larvae. J. Fish Biol. 2012, 80, 555-571. [CrossRef] [PubMed]

7. Symonds, J.E.; Walker, S.P.; Pether, S.; Gublin, Y.; McQueen, D.; King, A.; Irvine, G.W.; Setiawan, A.N.; Forsythe, J.A.; Bruce, M. Developing yellowtail kingfish (Seriola lalandi) and hāpuku (Polyprion oxygeneios) for New Zealand aquaculture. N. Z. J. Mar. Freshw. Res. 2014, 48, 371-384. [CrossRef]

8. Wylie, M.J.; Setiawan, A.N.; Irvine, G.W.; Symonds, J.E.; Elizur, A.; Dos Santos, M.; Lokman, P.M. Ovarian development of captive F1 wreckfish (hapuku) Polyprion oxygeneios under constant and varying temperature regimes-Implications for broodstock management. Gen. Comp. Endocrinol. 2018, 257, 86-96. [CrossRef] [PubMed]

9. Fauvel, C.; Suquet, M.; Sévère, A.; Mylonas, C.C.; Papandroulakis, N. Slow-release GnRHa therapy prevented atresia during vitellogenesis and induced ovulation of captive wreckfish (Polyprion americanus). Cybium 2008, $32,191$.

10. Mylonas, C.C.; Zohar, Y. Controlling reproduction in aquaculture. In New Technologies in Aquaculture: Improving Production Efficiency, Quality and Environmental Management; Burnell, G., Allan, G., Eds.; Woodhead Publishing Ltd.: Cambridge, UK, 2009; pp. 109-142. 
11. Mylonas, C.C.; Fostier, A.; Zanuy, S. Broodstock management and hormonal manipulations of fish reproduction. Gen. Comp. Endocrinol. 2010, 165, 516-534. [CrossRef] [PubMed]

12. Perez, L.; Penaranda, D.S.; Dufour, S.; Baloche, S.; Palstra, A.P.; Van Den Thillart, G.E.; Asturiano, J.F. Influence of temperature regime on endocrine parameters and vitellogenesis during experimental maturation of European eel (Anguilla anguilla) females. Gen. Comp. Endocrinol. 2011, 174, 51-59. [CrossRef] [PubMed]

13. Mylonas, C.C.; Papandroulakis, N.; Smboukis, A.; Papadaki, M.; Divanach, P. Induction of spawning of cultured greater amberjack (Seriola dumerili) using GnRHa implants. Aquaculture 2004, 237, 141-154. [CrossRef]

14. Zupa, R.; Rodríguez, C.; Mylonas, C.C.; Rosenfeld, H.; Fakriadis, I.; Papadaki, M.; Pérez, J.A.; Pousis, C.; Basilone, G.; Corriero, A. Comparative study of reproductive development in wild and captive-reared greater amberjack Seriola dumerili (Risso, 1810). PLoS ONE 2017, 12, e0169645. [CrossRef] [PubMed]

15. Mylonas, C.C.; Mitrizakis, N.; Papadaki, M.; Sigelaki, I. Reproduction of hatchery-produced meagre Argyrosomus regius in captivity I. Description of the annual reproductive cycle. Aquaculture 2013, 414-415, 309-317. [CrossRef]

16. Micale, V.; Perdichizzi, F.; Basciano, G. Aspects of the reproductive biology of the sharpsnout seabream Diplodus puntazzo (Cetti, 1777). I. gametogenesis and gonadal cycle in captivity during the third year of life. Aquaculture 1996, 140, 281-291. [CrossRef]

17. Papadaki, M.; Mazzella, D.; Santinelli, V.; Fakriadis, I.; Sigelaki, I.; Mylonas, C.C. Hermaphroditism and reproductive function of hatchery-produced sharpsnout seabream (Diplodus puntazzo) under attenuated annual thermal cycles. Aquaculture 2018, 482, 231-240. [CrossRef]

18. Guzmán, J.M.; Norberg, B.; Ramos, J.; Mylonas, C.C.; Mañanos, E. Vitellogenin, steroid plasma levels and spawning performance of cultured Senegalese sole (Solea senegalensis). Gen. Comp. Endocrinol. 2008, 156, 285-297. [CrossRef] [PubMed]

19. Mylonas, C.C.; Duncan, N.J.; Asturiano, J.F. Hormonal manipulations for the enhancement of sperm production in cultured fish and evaluation of sperm quality. Aquaculture 2017, 472, 21-44. [CrossRef]

20. Peñaranda, D.S.; Pérez, L.; Gallego, V.; Jover, M.; Tveiten, H.; Baloche, S.; Dufour, S.; Asturiano, J.F. Molecular and physiological study of the artificial maturation process in European eel males: From brain to testis. Gen. Comp. Endocrinol. 2010, 166, 160-171. [CrossRef] [PubMed]

21. Tsagarakis, K.; Başusta, A.; Başusta, N.; Biandolino, F.; Bostanci, D.; Buz, K.; Djodjo, Z.; Dulčić, J.; Gökoğlu, M.; Gücü, A.C.; et al. New Fisheries-related data from the Mediterranean Sea (October 2015). Mediterr. Mar. Sci. 2015, 16, 703-713. [CrossRef]

22. Carbonara, P.; Costantino, G.; Giovine, G.; Lembo, G.; Spedicato, M.T.; Machias, A. Some aspects of the life history of Polyprion americanus (Schneider, 1801) along the coasts of the North Western Ionian Sea. Biol. Mar. Medit. 2003, 10, 102-112.

23. Papandroulakis, N.; Mylonas, C.C.; Syggelaki, E.; Katharios, P.; Divakaran, S. First reproduction of captive-reared wreckfish (Polyprion americanus) using GnRH implants. Eur. Aquacult. 2008, 8, 15-18.

24. Peleteiro, J.B.; Saavedra Penas, C.; Rial, E.P.; Álvarez-Blázquez, B.; Soares, E.C.; Perón, A.V. Diversificación de especies en acuicultura. Estudio preliminar de la reproducción de la cherna (Polyprion americanus) en cautividad. In Proceedings of the Congreso Nacional de Acuicultura, Castelldefels, Spain, 21-24 November 2011.

25. Wakefield, C.B.; Newman, S.J.; Molony, B.W. Age-based demography and reproduction of hapuku, Polyprion oxygeneios, from the south coast of Western Australia: Implications for management. ICES J. Mar. Sci. 2010, 67, 1164-1174. [CrossRef]

26. Martínez-Vázquez, J.M.; Pérez-Rial, E.; Peleteiro, J.B.; Linares, F.; Rodríguez, J.L.; Vilar, A.; Cal, R.; Álvarez-Blázquez, B. Description of the wreckfish (Polyprion americanus) reproductive cycle in captivity. In Proceedings of the European Aquaculture 2016, Edinburgh, UK, 20-23 September 2016.

27. Duarte, C.M.; Alcaraz, M. To produce many small or few large eggs: A size-independent reproductive tactic of fish. Oecologia 1989, 80, 401-404. [CrossRef] [PubMed]

28. Mylonas, C.C.; Papadaki, M.; Pavlidis, M.; Divanach, P. Evaluation of egg production and quality in the Mediterranean red porgy (Pagrus pagrus) during two consecutive spawning seasons. Aquaculture 2004, 232, 637-649. [CrossRef] 
29. Cerdá, J.; Carrillo, M.; Zanuy, S.; Ramos, J.; de la Higuera, M. Influence of nutritional composition of diet on sea bass, Dicentrarchus labrax L.; reproductive performance and egg and larval quality. Aquaculture 1994, 128, 345-361. [CrossRef]

30. Kennedy, J.; Geffen, A.J.; Nash, R.D.M. Maternal influences on egg and larval characteristics of plaice (Pleuronectes platessa L.). J. Sea Res. 2007, 58, 65-77. [CrossRef]

31. Brown, N.P.; Shields, R.J.; Bromage, N.R. The influence of water temperature on spawning patterns and egg quality in the Atlantic halibut (Hippoglossus hippoglossus L.). Aquaculture 2006, 261, 993-1002. [CrossRef]

32. Sedberry, G.R.; Andrade, C.A.P.; Carlin, J.L.; Chapman, R.W.; Luckhurst, B.E.; Manooch, C.S.; Menezes, G.; Thomsen, B.; Ulrich, G.F. Wreckfish Polyprion americanus in the North Atlantic: Fisheries, biology and management of a widely distributed and long-lived fish. Am. Fish Soc. Symp. 1999, 23, 27-50.

33. Papadakis, I.E.; Kentouri, M.; Divanach, P.; Mylonas, C.C. Ontogeny of the eye of meagre (Argyrosomus regius) from hatching to juvenile and implications to commercial larval rearing. Aquaculture 2018, 484, $32-43$. [CrossRef]

34. Papadakis, I.; Kentouri, M.; Divanach, P.; Mylonas, C.C. Ontogeny of the digestive system of meagre Argyrosomus regius reared in a mesocosm, and quantitative changes of lipids in the liver from hatching to juveniles. Aquaculture 2013, 388-391, 76-88. [CrossRef]

35. Lowerre-Barbieri, S.K.; Ganias, K.; Saborido-Rey, F.; Murua, H.; Hunter, J.R. Reproductive timing in marine fishes: Variability, temporal scales, and methods. Mar. Coast. Fish. 2011, 3, 71-91. [CrossRef]

36. Gunnarsson, Á.; Hjörleifsson, E.; Thórarinsson, K.; Marteinsdóttir, G. Growth, maturity and fecundity of wolffish Anarhichas lupus L. in Icelandic waters. J. Fish Biol. 2006, 68, 1158-1176. [CrossRef]

37. Gunnarsson, Á.; Hjörleifsson, E.; Thórarinsson, K.; Marteinsdóttir, G. Growth, maturity and fecundity of female spotted wolffish Anarhichas minorin Icelandic waters. J. Fish Biol. 2008, 73, 1393-1406. [CrossRef]

38. Rideout, R.M.; Maddock, D.M.; Burton, M.P.M. Oogenesis and the spawning pattern in Greenland halibut from the North-west Atlantic. J. Fish Biol. 1999, 54, 196-207. [CrossRef]

39. Skjæraasen, J.E.; Nash, R.D.M.; Korsbrekke, K.; Fonn, M.; Nilsen, T.; Kennedy, J.; Nedreaas, K.H.; Thorsen, A.; Witthames, P.R.; Geffen, A.J.; et al. Frequent skipped spawning in the world's largest cod population. Proc. Natl. Acad. Sci. USA 2012, 109, 8995-8999. [CrossRef] [PubMed]

40. Rideout, R.M.; Rose, G.A.; Burton, M.P.M. Skipped spawning in female iteroparous fishes. Fish Fish. 2005, 6, 50-72. [CrossRef]

41. Zupa, R.; Corriero, A.; Deflorio, M.; Santamaria, N.; Spedicato, D.; Marano, C.; Losurdo, M.; Bridges, C.R.; De Metrio, G. A histological investigation of the occurence of non-reproductive female bluefin tuna Thunnus thynnus in the Mediterranean Sea. J. Fish Biol. 2009, 75, 1221-1229. [CrossRef] [PubMed]

42. Tromp, J.J.; Jones, P.L.; Symonds, J.E.; Walker, S.P.; Pope, A.; Pether, S.M.J.; Afonso, L.O.B. Effects of commercial diets and temperature on the growth performance and stress response of hapuku (Polyprion oxygeneios). Aquaculture 2016, 452, 128-133. [CrossRef]

43. Zohar, Y.; Muñoz-Cueto, J.A.; Elizur, A.; Kah, O. Neuroendocrinology of reproduction in teleost fish. Gen. Comp. Endocrinol. 2010, 165, 438-455. [CrossRef] [PubMed]

44. Rosenfeld, H.; Meiri, I.; Elizur, A. Gonadotropin regulation of oocyte development. In The Fish Oocyte: From Basic Studies to Biotechnological Applications; Babin, P.J., Cerdá, J., Lubzens, E., Eds.; Kluwer Academic Publishers: Dordrecht, The Netherlands, 2007; pp. 171-198.

45. Lubzens, E.; Young, G.; Bobe, J.; Cerdá, J. Oogenesis in teleosts: How fish eggs are formed. Gen. Comp. Endocrinol. 2010, 165, 36-389. [CrossRef] [PubMed]

46. Scott, A.P.; Sumpter, J.P.; Stacey, N. The role of the maturation-inducing steroid, 17,20ß-dihydroxypregn4-en-3-one, in male fishes: A review. J. Fish Biol. 2010, 76, 183-224. [CrossRef] [PubMed]

47. Nagahama, Y.; Yamashita, M. Regulation of oocyte maturation in fish. Dev. Growth Differ. 2008, 50, S195-S219. [CrossRef] [PubMed]

48. Tokumoto, T.; Yamaguchi, T.; Ii, S.; Tokumoto, M. In vivo induction of oocyte maturation and ovulation in zebrafish. PLoS ONE 2011, 6, e25206. [CrossRef] [PubMed]

49. Bobe, J.; Montfort, J.; Nguyen, T.; Fostier, A. Identification of new participants in the rainbow trout (Oncorhynchus mykiss) oocyte maturation and ovulation processes using cDNA microarrays. Reprod. Biol. Endocrinol. 2006, 4, 39. [CrossRef] [PubMed]

50. Kjesbu, O.S.; Kryvi, H.; Norberg, B. Oocyte size and structure in relation to blood plasma steroid hormones in individually monitored, spawning Atlantic cod. J. Fish Biol. 1996, 49, 1197-1215. [CrossRef] 
51. Jeng, S.R.; Yueh, W.S.; Lee, Y.H.; Yen, H.F.; Chang, C.F. 17,20ß,21-Trihydroxy-4-pregnen-3-one biosynthesis and $20 \beta$-hydroxysteroid dehydrogenase expression during final oocyte maturation in the protandrous yellowfin porgy, Acanthopagrus latus. Gen. Comp. Endocrinol. 2012, 176, 192-200. [CrossRef] [PubMed]

52. García-López, A.; Anguis, V.; Couto, E.; Canario, A.V.M.; Cañavate, J.P.; Sarasquete, C.; Martínez-Rodríguez, G. Non-invasive assessment of reproductive status and cycle of sex steroid levels in a captive wild broodstock of Senegalese sole Solea senegalensis (Kaup). Aquaculture 2006, 254, 583-593. [CrossRef]

53. Fauvel, C.; Suquet, M.; Cosson, J. Evaluation of fish sperm quality. J. Appl. Ichthyol. 2010, 26, 636-643. [CrossRef]

54. Mylonas, C.C.; Papadaki, M.; Divanach, P. Seasonal changes in sperm production and quality in the red porgy Pagrus pagrus (L.). Aquacult. Res. 2003, 34, 1161-1170. [CrossRef]

55. Papadaki, M.; Papadopoulou, M.; Siggelaki, I.; Mylonas, C.C. Egg and sperm production and quality of sharpsnout sea bream (Diplodus puntazzo) in captivity. Aquaculture 2008, 276, 187-197. [CrossRef]

56. Zupa, R.; Fauvel, C.; Mylonas, C.C.; Pousis, C.; Santamaria, N.; Papadaki, M.; Fakriadis, I.; Cicirelli, V.; Mangano, S.; et al. Rearing in captivity affects spermatogenesis and sperm quality in greater amberjack, Seriola dumerili (Risso, 1810). J. Anim. Sci. 2017, 95, 4085-4100. [CrossRef] [PubMed]

57. Suquet, M.; Cosson, J.; de la Gándara, F.; Mylonas, C.C.; Papadaki, M.; Lallemant, S.; Fauvel, C. Sperm features of captive Atlantic bluefin tuna (Thunnus thynnus). J. Appl. Ichthyol. 2010, 26, 775-778. [CrossRef]

58. Schulz, R.W.; de França, L.R.; Lareyre, J.-J.; LeGac, F.; Chiarini-Garcia, H.; Nobrega, R.H.; Miura, T. Spermatogenesis in fish. Gen. Comp. Endocrinol. 2010, 165, 390-411. [CrossRef] [PubMed]

59. Schulz, R.W.; Miura, T. Spermatogenesis and its endocrine regulation. Fish Physiol. Biochem. 2002, 26, 43-56. [CrossRef]

60. Borg, B. Androgens in teleost fishes. Comp. Biochem. Physiol. 1994, 109, 219-245. [CrossRef]

61. Dahle, R.; Taranger, G.L.; Karlsen, Ø.; Kjesbu, O.S.; Norberg, B. Gonadal development and associated changes in liver size and sexual steroids during the reproductive cycle of captive male and female Atlantic cod (Gadus morhua L.). Comp. Biochem. Physiol. Part A Mol. Integr. Physiol. 2003, 136, 641-653. [CrossRef]

62. García-López, A.; Fernandez-Pasquier, V.; Couto, E.; Canario, A.V.; Sarasquete, C.; Martinez-Rodriguez, G. Testicular development and plasma sex steroid levels in cultured male Senegalese sole Solea senegalensis Kaup. Gen. Comp. Endocrinol. 2006, 147, 343-351. [CrossRef] [PubMed]

63. Guzmán, J.M.; Ramos, J.; Mylonas, C.C.; Manaños, E. Spawning performance and plasma levels of GnRHa and sex steroids in cultured female Senegalese sole (Solea senegalensis) treated with different GnRHa-delivery systems. Aquaculture 2009, 291, 200-209. [CrossRef]

64. Guzmán, J.M.; Ramos, A.G.; Mylonas, C.C.; Mananos, E. Comparative effects of human chorionic gonadotropin (hCG) and gonadotropin-releasing hormone agonist (GnRHa) treatments on the stimulation of male Senegalese sole (Solea senegalensis) reproduction. Aquaculture 2011, 316, 121-128. [CrossRef]

65. Norambuena, F.; Mackenzie, S.; Bell, J.G.; Callol, A.; Estévez, A.; Duncan, N. Prostaglandin (F and E, 2and 3-series) production and cyclooxygenase (COX-2) gene expression of wild and cultured broodstock of senegalese sole (Solea senegalensis). Gen. Comp. Endocrinol. 2012, 177, 256-262. [CrossRef] [PubMed]

66. Kohn, Y.Y.; Symonds, J.E. Evaluation of egg quality parameters as predictors of hatching success and early larval survival in hapuku (Polyprion oxygeneios). Aquaculture 2012, 342-343, 42-47. [CrossRef]

67. Linares, F.; Rodriguez, J.L.; Peleteiro, J.B.; Cal, R.; Pazos, G.; Álvarez-Blázquez, B. Biochemical composition of wild wreckfish (Polyprion americanus). In Proceedings of the Aquaculture Europe 2015, Rotterdam, The Netherlands, 21-23 October 2015.

68. Linares, F.; Rodriguez, J.L.; Peleteiro, J.B.; Cal, R.; Martínez, J.M.; Pazos, G.; Álvarez-Blázquez, B. Influence of broodstock nutrition of wreckfish (Polyprion americanus) on the oocytes fatty acid composition. In Proceedings of the Aquaculture Europe 2015, Edinbourg, UK, 20-23 September 2016.

69. Anonymous. Guidelines for the treatment of animals in behavioural research and teaching. Anim. Behav. 1998, 55, 251-257.

70. Metcalfe, J.D.; Craig, J.F. Ethical justification for the use and treatment of fishes in research: An update. J. Fish Biol. 2011, 78, 393-394. [CrossRef] [PubMed]

71. EU. Directive 2010/63/EU of the European Parliament and the Council of 22 September 2010 on the Protection of Animals Used for Scientific Purposes; Official Journal of the European Union L 276/33; Animal Protection: London, UK, 2010. 
72. Mylonas, C.C.; Cardinaletti, G.; Sigelaki, I.; Polzonetti-Magni, A. Comparative efficacy of clove oil and 2-phenoxyethanol as anesthetics in the aquaculture of European sea bass (Dicentrarchus labrax) and gilthead sea bream (Sparus aurata) at different temperatures. Aquaculture 2005, 246, 467-481. [CrossRef]

73. Bennett, H.S.; Wyrick, A.D.; Lee, S.W.; McNeil, J.H. Science and art in preparing tissues embedded in plastic for light microscopy, with special reference to glycol methacrylate, glass knives and simple stains. Stain Technol. 1976, 51, 71-97. [CrossRef] [PubMed]

74. Cuisset, B.; Pradelles, P.; Kime, D.E.; Kühn, E.R.; Babin, P.; Davail, S.; Le Menn, F. Enzyme immunoassay for 11-ketotestosterone using acetylcholinesterase as label: Application to the measurement of 11-ketotestosterone in plasma of Siberian sturgeon. Comp. Biochem. Physiol. 1994, 108C, $229-241$.

75. Nash, J.P.; Davail-Cuisset, B.; Bhattacharyya, S.; Suter, H.C.; Le Menn, F.; Kime, D.E. An enzyme linked immunosorbent assay (ELISA) for testosterone, estradiol, and 17,20ß-dihydroxy-4-pregnen-3-one using acetylcholinesterase as tracer: Application to measurement of diel patterns in rainbow trout (Oncorhynchus mykiss). Fish Physiol. Biochem. 2000, 22, 355-363. [CrossRef]

76. Rodríguez, L.; Begtashi, I.; Zanuy, S.; Carrillo, M. Development and validation of an enzyme immunoassay for testosterone: Effects of photoperiod on plasma testosterone levels and gonadal development in male sea bass (Dicentrarchus labrax L.) at puberty. Fish Physiol. Biochem. 2000, 23, 141-150. [CrossRef]

(C) 2018 by the authors. Licensee MDPI, Basel, Switzerland. This article is an open access article distributed under the terms and conditions of the Creative Commons Attribution (CC BY) license (http:/ / creativecommons.org/licenses/by/4.0/). 